\title{
MAGE-3.A1 Peptide Vaccine
}

National Cancer Institute

\section{Source}

National Cancer Institute. MAGE-3.A1 Peptide Vaccine. NCI Thesaurus. Code C48632.

A synthetic peptide cancer vaccine consisting of human leukocyte antigen HLA-A1restricted peptide derived from human melanoma antigen 3 (MAGE-3) with potential immunostimulating and antineoplastic activities. Upon administration, MAGE-3.A1 peptide vaccine may stimulate the immune system to mount a cytotoxic $T$-cell $(C T L)$ response against tumor cells expressing MAGE-3, resulting in tumor cell lysis. MAGE-3, a tumorassociated antigen (TAA), is overexpressed by a variety of cancer cell types. 